\title{
PENGARUH SIT STRETCHING TERHADAP PERUBAHAN SKALA NYERI PUNGGUNG BAWAH PADA KARYAWAN DI PT. RIFAN FINANCINDO BERJANGKA CABANG SEMARANG
}

\author{
Gamaliel Anggriya Dwi Putra ${ }^{1}$, Asti Nuraeni ${ }^{2}$, Mamat Supriyono ${ }^{3}$ \\ ${ }^{1}$ Program Studi S1 Ilmu Keperawatan STIKES Telogorejo Semarang \\ ${ }^{2}$ Program Studi S1 Ilmu Keperawatan STIKES Telogorejo Semarang \\ ${ }^{3}$ Epidemiolog Kesehatan Dinas Kesehatan Kota Semarang \\ E-mail : asti@stikestelogorejo.ac.id
}

\begin{abstract}
ABSTRAK
Nyeri punggung bawah merupakan salah satu gangguan muskuloskeletal berupa rasa nyeri pada tulang belakang tepatnya pada lumbal keempat hingga sakrum pertama yang disebabkan oleh sikap tubuh yang kurang baik (tidak ergonomis) ketika berkerja atau beraktivitas, seperti berdiri atau duduk terlalu lama. Keluhan ini dapat berkurang dengan melakukan sit stretching secara rutin. Tujuan penelitian ini adalah untuk mengetahui pengaruh sit stretching terhadap perubahan skala nyeri punggung bawah pada karyawan di PT. Rifan Financindo Berjangka Cabang Semarang. Metode penelitian ini menggunakan quasy experiment dengan rancangan pre test dan post tes with compare group. Subyek penelitian berjumlah 30 karyawan yang berjenis kelamin laki-laki dan perempuan. Teknik pengambilan sampel menggunakan total sampling. Uji statistik menggunakan Mann Whitney dengan tingkat kemaknaan $(\alpha=0,05)$. Hasil uji statistik pre test diperoleh $p$-value $=0,467(>0,05)$, yang berarti tidak terdapat perbedaan bermakna skala nyeri punggung bawah kelompok intervensi dengan kelompok pembanding sebelum dilakukan sit stretching pada kelompok intervensi. Kemudian hasil uji statistik post test diperoleh $p$-value $=0,001(<0,05)$, yang berarti terdapat perbedaan bermakna skala nyeri punggung bawah kelompok intervensi dengan kelompok pembanding setelah dilakukan sit stretching pada kelompok intervensi. Berdasarkan hasil p-value pada post test dapat disimpulkan bahwa terdapat pengaruh sit stretching terhadap perubahan skala nyeri punggung bawah pada karyawan di PT. Rifan Financindo Berjangka Cabang Semarang.
\end{abstract}

Kata Kunci : Nyeri punggung bawah, sit stretching, karyawan

\section{ABSTRACT}

Lower back pain is one of musculoskeletal disorder in the shape of pain in the back bone, to be exact is in the forth lumbar to the first sacrum. It is caused by the not appropriate posture (not ergonomic) while working or doing the activities, such as very long standing or sitting. This complaint can be reduced by sit stretching regularly. The aim of this study is to find out impact of sit stretching towards the changes of scale of lower back pain on employees at PT. Rifan Financindo Berjangka Branch Semarang. The method of research is quasy experiment designed in pre test and post test with compare group. Research subjects are 30 male and female employees. Sample taking uses total sampling. Statisitic test utilizes Mann Whitney with level of meaning $(\alpha=0,05)$. The result of pre test statisitc test is p-value $=0,467$ (>0,05), it means that there is no significant difference scale of lower back pain between intervention group and compare group before performing sit stretching to intervention group. The post test statisitic the result is p-value =0,001 (>0,05), it means there is a significant difference scale of lower back pain at intervention group with compare group after performing sit stretching on the intervention group. Based on result of p-value on post test can be concluded that there is an impact of sit stretching towards the changes in scale of lower back pain on the employees at PT. Rifan Financindo Berjangka Branch Semarang.

Key Words : : Lower back pain, sit stretching, employees

\section{A. PENDAHULUAN}

Nyeri punggung bawah menurut Idyan (2007, dalam Lukman \& Ningsih, 2009, hlm. 127) merupakan salah satu gangguan muskuloskeletal yang disebabkan oleh postur tubuh yang tidak ergonomis ketika melakukan aktivitas.

Laporan-laporan beberapa negara, yaitu Republik Korea, Great Britain, dan Jepang kasus gangguan muskuloskletal 
(Musculoskeletal Disorders) meningkat di banyak negara (International Labour Organization, 2013), contohnya, di Republik Korea mencapai 5.502 kasus di tahun 2010. Persentase gangguan muskuloskeletal (Musculoskeletal Disorders) di Great Britain mencapai $40 \%$ pada semua pekerja. Kasus pneumoconiosis dan low back pain di Jepang menjadi masalah umum mencapai 7.779 kasus penyakit yang berhubungan dengan pekerjaan di tahun 2011, World Health Organization melaporkan bahwa jumlah gangguan muskuloskeletal (Musculoskeletal Disorders) mencapai 4\% pada tahun 2001 hingga 2014 (World Health Organization (WHO), 2014).

Prevalensi gangguan muskuloskeletal di Indonesia tahun 2013 yang didiagnosis oleh tenaga kesehatan, yaitu mencapai $24,7 \%$, prevalensi tertinggi berdasarkan pekerjaan adalah pada petani, nelayan, dan buruh mencapai 31,2\% (Riskesdas, 2013). Penelitian yang serupa dilakukan di Jawa Tengah tahun 2013 dengan hasil 77,3\% pekerja sektor informal memiliki risiko terkena nyeri punggung bawah karena adanya postur tubuh yang salah (Wulandari, 2013, I1). Berdasarkan hasil survei awal oleh Warapsari, Sugiyanto, dan Hartini (2014, I[16-8) mengatakan bahwa pada bulan Desember 2013 yang dilakukan peneliti dengan observasi dan wawancara terhadap 20 pekerja dari 85 pekerja dari 2 home industry yang ada di Kelurahan Bandengan Kecamatan Kendal. Hasil penelitian didapatakan $90 \%$ pekerja sering mengalami gejala nyeri punggung bawah selama dan setelah bekerja.

Dampak nyeri punggung bawah menurut Hawthorn \& Redmond (1998 dalam Kneale, 2011, hlm.163) adalah kelemahan otot progresif, keletihan tubuh, hubungan personal dan sosial terganggu, dan penurunan produktivitas pekerja, sehingga menyebabkan kerugian ekonomi bagi perusahaan tersebut. Selain itu, nyeri punggung bawah menyebabkan penyakit herniasi nukleus pulposus (HNP) atau penonjolan bantalan (nukleus pulposus) yang mengakibatkan syaraf terjepit (Lukman \& Ningsih, 2009, hlm. 128).
Peran perawat di lingkungan kerja (occupational health nursing), yaitu melakukan promosi kesehatan preventif, kuratif, dan reahabilitatif (Efendi \& Makhfuhli, 2009, hlm.233). Peran perawat di lingkungan kerja (occupational health nursing) sebagai kuratof, maka perawat di lingkungan kerja (occupational health nursing) dapat memberikan asuhan keperawatan pada pekerja yang mengalami keluhan nyeri punggung bawah dalam bentuk relaksasi, latihan fisik, dan peregangan (stretching) untuk mengurangi keluhan tersebut (Lukman \& Ningsih, 2009, hlm.130-131).

Peregangan (stretching) adalah latihan fisik yang berguna untuk mengurangi ketegangan otot, mempersiapkan tubuh sebelum beraktivitas, membuat tubuh lebih rileks, memperluas rentang gerak, menambah rasa nyaman, dan membantu mencegah cedera (Anderson, 2008, hlm.14). Salah satu peregengan yang dapat dilakukan untuk karyawan di kantor adalah sit stretching. Sit stretching adalah peregangan yang dilakukan dengan posisi duduk dan dapat dilakukan di sela-sela pekerjaan, karena durasinya hanya 5-10 menit. Inti dalam gerakan-gerakan sit stretching berguna untuk meregangkan otot punggung bawah yang mengalami kelelahan dan kekakuan akibat aktivitas yang statis, serta memperlancar peredaran darah di area punggung (Anderson, 2010, hlm. 60).

Tujuan penelitian ini untuk mengetahui pengaruh sit stretching terhadap perubahan skala nyeri punggung bawah pada karyawan PT. Rifan Financindo Berjangka Cabang Semarang.

\section{B. METODE PENELITIAN}

Rancangan penelitian yang digunakan oleh peneliti adalah rancangan penelitian semu eksperimen (quasy experiment), dengan pre test dan post tes with compare group.

Sampel dalam penelitian ini adalah karyawan yang mengalami nyeri punggung bawah yang memenuhi kriteria inklusi peneliti sejumlah 20 responden. Sampel kemudian dibagi menjadi 2 kelompok. Kelompok pertama (10 responden) merupakan kelompok perlakuan dan 
kelompok kedua (10 responden) merupakan kelompok pembanding. Peneliti menggunakan teknik pengambilan sampel jenuh (total sampling). Alat pengumpulan data atau instrumen yang digunakan dalam penelitian ini adalah lembar observasi skala nyeri.

Analisis univariat digunakan untuk mendapatkan gambaran karakteristik variabel yang diteliti, seperti jenis kelamin, usia, masa kerja, lama kerja setiap hari dan skala nyeri punggung bawah sebelum diberikan intervensi dan sesudah dilakukan intervensi. Analisis bivariat dilakukan untuk menguji perbedaan variabel yang diukur sebelum dan sesudah dilakukan intervensi pada kelompok intervensi dan kelompok pembanding. Data terlebih dahulu dilakukan uji normalitas, menggunakan Shaipro Wilk karena data berupa data numerik (interval), dengan jumlah 30 responden. Kemudian dilakukan uji statistik menggunakan uji bivariat menggunakan uji Mann Whitney dengan tingkat kemaknaan 95\% $(\alpha=0,05)$, karena memenuhi syarat : data numerik (interval), tidak berdistribusi normal, dan dua kelompok tidak berpasangan.

\section{HASIL DAN PEBAHASAN}

Hasil penelitian berupa gambaran karakteristik responden, meliputi : jenis kelamin, usia, lama duduk setiap hari, dan masa kerja serta skala nyeri sebelum dan sesudah diberikan intervensi.

1. Analisis Univariat

a. Karakteristik Responden

Karakteristik responden berupa usia, jenis kelamin, lama duduk setiap hari, dan masa kerja.

Tabel 4.1

Distribusi Frekuensi Responden Berdasarkan Jenis Kelamin di PT. Rifan Financindo Berjangka Cabang Semarang Bulan April 2017

$$
(n=30)
$$

\begin{tabular}{lrr}
\hline Jenis & Frekuensi & $\begin{array}{c}\text { Persentase } \\
(\%)\end{array}$ \\
Kelamin & \multicolumn{2}{c}{50} \\
\hline Laki-Laki & 15 & 50 \\
Perempuan & 15 & 5 \\
\hline
\end{tabular}

Berdasarkan tabel 4.1, jenis kelamin responden laki-laki dan perempuan sama banyak, yaitu 15 responden dengan persentase masing-masing $50 \%$.

Tabel 4.2

Distribusi Frekuensi Responden

Berdasarkan Usia di PT. Rifan

Financindo Berjangka Cabang

Semarang Bulan April 2017

$$
(n=30)
$$

\begin{tabular}{lrr}
\hline $\begin{array}{c}\text { Usia } \\
\text { (Tahun) }\end{array}$ & Frekuensi & $\begin{array}{r}\text { Persentase } \\
(\%)\end{array}$ \\
\hline$\leq 20$ & 3 & 10 \\
$21-30$ & 23 & 76,7 \\
$31-40$ & 4 & 13,3 \\
$41-50$ & - & 0 \\
& & \\
\hline
\end{tabular}

Berdasarkan tabel 4.2, usia responden paling banyak adalah usia dewasa awal dengan jumlah 23 responden (76,7\%), kemudian dewasa tengah dengan jumlah 4 responden (13,3\%), dan remaja akhir dengan 3 responden $(10 \%)$.

Tabel 4.3

Distribusi Frekuensi Responden Berdasarkan Lama Duduk Setiap di Kantor di PT. Rifan Financindo Berjangka Cabang Semarang Bulan April 2017 $(\mathrm{n}=30)$

\begin{tabular}{lrr}
\hline $\begin{array}{l}\text { Lama } \\
\text { Duduk di }\end{array}$ & Frekuensi & $\begin{array}{c}\text { Persentase } \\
(\%)\end{array}$ \\
$\begin{array}{l}\text { Kantor } \\
\text { (jam) }\end{array}$ & \multicolumn{2}{c}{} \\
\hline $1-3$ & 6 & 20 \\
$4-6$ & 6 & 20 \\
$>6$ & 18 & 60 \\
\hline
\end{tabular}

Berdasarkan tabel 4.3, lama duduk responden di kantor paling banyak adalah > 6 jam dengan jumlah 18 responden $(60 \%)$, kemudian 1-3 jam dan 4-6 jam dengan jumlah yang sama, yaitu 6 responden (20\%).

Tabel 4.4 
Distribusi Frekuensi Responden

Berdasarkan Masa Kerja di PT. Rifan

Financindo Berjangka Cabang

Semarang Bulan April 2017

$$
(n=30)
$$

\begin{tabular}{lcc}
\hline $\begin{array}{l}\text { Masa } \\
\text { Kerja } \\
\text { (tahun) }\end{array}$ & Frekuensi & $\begin{array}{c}\text { Persentase } \\
(\%)\end{array}$ \\
\hline
\end{tabular}

\begin{tabular}{rrr}
\hline$\leq 5$ & 28 & 93,3 \\
$>5$ & 2 & 6,7 \\
\hline
\end{tabular}

Berdasarkan tabel 4.4, masa kerja responden paling banyak adalah $\leq 5$ tahun dengan jumlah 28 responden $(93,3 \%)$, kemudian $>5$ tahun dengan jumlah 2 responden $(6,7 \%)$.

b. Gambaran Skala Nyeri Punggung Bawah Sebelum dan Sesudah Diberikan Sit Stretching pada Kelompok Intervensi.

Tabel 4.5

Distribusi Frekuensi Responden Berdasarkan Skala Nyeri Punggung Bawah Sebelum dan Sesudah Diberikan Sit Stretching pada Kelompok Intervensi di PT. Rifan Financindo

$$
\text { Berjangka }
$$

Cabang Semarang Bulan April 2017

\begin{tabular}{|c|c|c|c|c|c|}
\hline \multirow[b]{2}{*}{ No } & \multirow{2}{*}{ Skala Nyeri } & \multicolumn{2}{|c|}{ Sebelum } & \multicolumn{2}{|c|}{ Sesudah } \\
\hline & & $\mathrm{f}$ & $\%$ & $f$ & $\%$ \\
\hline 1 & 0 & 0 & 0 & 6 & 40 \\
\hline 2 & 1 & 3 & 20 & 5 & 33,3 \\
\hline 3 & 2 & 0 & 0 & 3 & 20 \\
\hline 4 & 3 & 6 & 40 & 1 & 6,7 \\
\hline 5 & 4 & 4 & 26,7 & 0 & 0 \\
\hline 6 & 5 & 0 & 0 & 0 & 0 \\
\hline 7 & 6 & 2 & 13,3 & 0 & 0 \\
\hline 8 & 7 & 0 & 0 & 0 & 0 \\
\hline 9 & 8 & 0 & 0 & 0 & 0 \\
\hline 10 & 9 & 0 & 0 & 0 & 0 \\
\hline 11 & 10 & 0 & 0 & 0 & 0 \\
\hline Jun & & 15 & 100 & 15 & 100 \\
\hline
\end{tabular}

$$
(\mathrm{n}=15)
$$

Berdasarkan tabel 4.5 , skala nyeri punggung sebelum diberikan sit stretching pada kelompok intervensi dengan jumlah 15 responden, yaitu sebanyak 3 responden $(60 \%)$ pada skala 1 , sebanyak 6 responden $(40 \%)$ pada skala 3 , sebanyak 4 responden (26,7\%) pada skala 4 , sebanyak 2 responden $(13,3 \%)$ pada skala 6 , dan tidak ada responden pada skala $0,2,5,7,8,9$, dan 10. Skala nyeri punggung sesudah diberikan sit stretching pada kelompok intervensi dengan jumlah 15 responden, yaitu sebanyak 6 responden (40\%) pada skala 0 , dan sebanyak 5 responden
$(33,3 \%)$ pada skala 1 , sebanyak 3 responden $(20 \%)$ pada skala 2,1 responden $(6,7 \%)$ pada skala 3 dan tidak tidak ada responden pada skala 4 hingga 10. 
c. Gambaran Skala Nyeri Punggung Bawah pada Kelompok Pembanding.

$$
\text { Tabel } 4.6
$$

Distribusi Frekuensi Responden Berdasarkan Pre Test dan Post Test Skala Nyeri

Punggung Bawah pada Kelompok Pembanding

di PT. Rifan Financindo Berjangka Cabang Semarang

\section{Bulan April 2017}

$$
(n=15)
$$

\begin{tabular}{rrrrrrr}
\hline \multirow{2}{*}{ No } & \multirow{2}{*}{$\begin{array}{c}\text { Skala } \\
\text { Nyeri }\end{array}$} & $\mathrm{f}$ & \multicolumn{3}{c}{ Pre Test } & \multicolumn{3}{c}{ Post Test } \\
\hline 1 & 0 & & 0 & $\mathrm{f}$ & & $\%$ \\
2 & 1 & 3 & 20 & 1 & 6,7 \\
3 & 2 & 3 & 20 & 2 & 13,3 \\
4 & 3 & 5 & 33,3 & 3 & 20 \\
5 & 4 & 0 & 0 & 5 & 33,3 \\
6 & 5 & 4 & 26,7 & 0 & 0 \\
7 & 6 & 0 & 0 & 3 & 0 \\
8 & 7 & 0 & 0 & 0 & 0 \\
9 & 8 & 0 & 0 & 0 & 0 \\
10 & 9 & 0 & 0 & 0 & 0 \\
11 & 10 & 0 & 0 & 0 & 0 \\
& & & & & & 0 \\
\hline Jumlahyyyyy & & 15 & 100 & 15 & 100 \\
\hline
\end{tabular}

Berdasarkan tabel 4.6 , pre test skala nyeri punggung pada kelompok pembanding dengan jumlah 15 responden, yaitu sebanyak 3 responden (20\%) pada skala 1 , sebanyak 3 responden $(20 \%)$ pada skala 2 , sebanyak 5 responden $(33,3 \%), 4$ responden $(26,7 \%)$ pada skala 5 , dan tidak ada responden pada skala $0,4,6,7,8,9$, dan 10 . Pada post test skala nyeri punggung pada kelompok pembanding dengan jumlah 15 responden, yaitu sebanyak 1 responden $(6,7 \%)$ pada skala 0 , sebanyak 2 responden $(13,3 \%)$ pada skala 1 , sebanyak 3 responden (20\%) pada skala 2 , sebanyak 5 responden $(33,3 \%)$ pada skala 3, sebanyak 3 responden $(20 \%)$ pada skala 5 , sebanyak 1 responden (6,7\%) pada skala 7 dan tidak ada responden pada skala 4,6,8,9, dan 10 . 
2. Analisis Bivariat

a. Hasil Uji Normalitas Skala Nyeri Punggung Bawah Kelompok Intervensi dan Kelompok Pembanding Tabel 4.7

Hasil Uji Normalitas Skala Nyeri Punggung Bawah

Kelompok Intervensi dan Kelompok Pembanding

$(\mathrm{n}=30)$

\begin{tabular}{llrrr}
\hline \multirow{2}{*}{ Variabel } & \multirow{2}{*}{ Kelompok } & \multicolumn{3}{c}{ Shapiro-Wilk } \\
\cline { 3 - 5 } & & Statistik & \multicolumn{1}{c}{$\mathrm{df}$} & p-value \\
\hline Skala Nyeri & Intervensi & 0,881 & 15 & 0,050 \\
Pre Test $)$ & Pembanding & 0,863 & 15 & 0,027 \\
Skala Nyeri & Intervensi & 0,844 & 15 & 0,014 \\
$($ Post Test) & Pembanding & 0,938 & 15 & 0,363 \\
& & & & \\
\hline
\end{tabular}

Berdasarkan tabel 4.7, hasil uji normalitas dengan menggunakan Shapiro-Wilk (responden $(\mathrm{n}=30) \leq 50)$ menunjukkan $p$-value skala nyeri (pre test) kelompok intervensi adalah 0,050 $(p$-value $=0,05)$ yang berarti data berdistribusi normal dan pada kelompok pembanding adalah 0,027 ( $p$-value < 0,05 ) yang berarti data tidak berdistribusi normal. Sedangkan, $p$-value skala nyeri (post test) kelompok intervensi adalah 0,014 ( $p$-value $<0,05$ ), yang berarti data tidak berdistribusi normal, dan pada kelompok pembanding adalah 0,363 ( $p$ value > 0,05) yang berarti data berdistribusi normal. Berdasarkan hasil $p$-value di atas dapat disimpulkan bahwa data tidak berdistribusi normal.

b. Pengaruh Sit Stretching terhadap Perubahan Skala Nyeri Punggung Bawah di PT. Rifan Financindo Berjangka Cabang Semarang

Tabel 4.8

Perbandingan Pre Test Skala Nyeri Punggung Bawah

Kelompok Intervensi dengan Kelompok Pembanding

$(n=30)$

\begin{tabular}{lrrr}
\hline Kelompok & Frekuensi & Mean Rank & p-value \\
\hline Intervensi & 15 & 16,63 & 0,467 \\
Pembanding & 15 & 14,37 & \\
\end{tabular}

Berdasarkan tabel 4.8, menunjukkan mean rank kelompok intervensi 16,63 dan mean rank kelompok pembanding 14,37 , hal ini berarti bahwa mean rank kelompok pembanding lebih kecil dibanding dengan mean rank kelompok intervensi. Hasil uji Mann Whitney diperolah hasil p-value 0,467. Hasil tersebut berarti $p$-value $>\alpha(0,05)$, maka dapat disimpulkan bahwa tidak terdapat perbedaan bermakna skala nyeri punggung bawah kelompok intervensi dengan kelompok pembanding saat pre test. 
Tabel 4.9

Perbandingan Post Test Skala Nyeri Punggung Bawah

Kelompok Intervensi dengan Kelompok Pembanding

$(\mathrm{n}=30)$

\begin{tabular}{lrrr}
\hline Kelompok & Frekuensi & Mean Rank & p-value \\
& & & 0,001 \\
\hline Intervensi & 15 & 10,33 & \\
Pembanding & 15 & 20,67 &
\end{tabular}

Berdasarkan tabel 4.9, menunjukkan mean rank kelompok intervensi 10,33 dan mean rank kelompok pembanding 20,67, hal ini berarti bahwa mean rank kelompok intervensi lebih kecil dibanding dengan mean rank kelompok pembanding. Hasil uji Mann Whitney diperolah hasil p-value 0,001. Hasil tersebut berarti $p$-value $<\alpha(0,05)$, maka terdapat perbedaan bermakna skala nyeri punggung bawah kelompok intervensi dengan kelompok pembanding saat post test.

Hasil uji Mann Whitney pada tabel 4.8 dan 4.9 menunjukkan mean rank kelompok intervensi terjadi penurunan dari 16,63 menjadi 10,33 sedangkan mean rank kelompok pembanding terjadi peningkatan dari 14,37 menjadi 20,67. $P$ -

3. Pembahasan

a.Karakteristik Responden

Hasil analisis jenis kelamin menunjukkan bahwa nyeri punggung bawah dialami oleh laki-laki dan perempuan dengan jumlah yang sama, yaitu 15 responden $(50 \%)$. Berdasarkan hasil observasi di lapangan, jenis kelamin karyawan laki-laki dan perempuan sama rata. Pekerjaan pada bagian tertentu seperti, driver semua karyawan berjenis kelamin laki-laki dan bagian sekretaris semua karyawan berjenis kelamin perempuan. Penempatan bagian kerja tersebut (driver dan sekretaris) sesuai dengan keterampilan dan kemampuan yang dimiliki oleh masing-masing individu. value skala nyeri punggung bawah saat pre test diperoleh hasil $0,467(>0,05)$ dan $p$-value skala nyeri punggung bawah saat post test diperoleh hasil 0,001 $(<0,05)$, maka dapat disimpulkan terdapat perbedaan skala nyeri punggung bawah kelompok intervensi dengan kelompok pembanding saat pre test dan post test. Berdasarkan hasil mean rank kelompok intervensi yang mengalami penurunan dan p-value yang menunjukkan adanya perbedaan skala nyeri punggung bawah kelompok intervesi dan kelompok pembanding, maka H0 ditolak dan Ha diterima. Peneliti menarik kesimpulan bahwa terdapat pengaruh sit stretching terhadap perubahan skala nyeri punggung bawah pada karyawan di PT Rifan Financindo Berjangka Cabang Semarang.

Driver lebih cocok untuk jenis kelamin laki-laki karena pekerjaan tersebut membutuhkan kensentrasi dan tenaga yang lebih dibandingkan dengan sekretaris yang lebih menekankan pada ketelitian dan kerapian, sehingga bagian sekretaris lebih cocok bagi perempuan.

Teori Singha (2014, dalam Maulana 2014, II 1-10) yang mengatakan bahwa sekarang nyeri punggung bawah tidak hanya menyerang usia tua saja, tetapi usia muda pun sekarang banyak yang mengalami nyeri punggung bawah, seperti pada kalangan mahasiswa dan pekerja kantoran. Nyeri punggung bawah 
pada usia muda disebabkan karena mereka kurang olahraga, aktivitas statis seperti terlalu banyak banyak duduk pada posisi yang sama dalam jangka waktu yang lama, misalnya belajar atau bekerja di balik meja. Bahkan duduk dengan posisi tubuh membungkuk saat membaca, menulis, berkerja di depan laptop, mengemudi kendaraan. Kondisi inilah yang menyebabkan terjadinya nyeri punggung bawah. Selain itu, orang muda di kota memiliki tingkat konsumsi makanan yang tinggi dan kurang olahraga, sehingga mengalami obesitas. Semakin meningkat berat badan seseorang maka, semakin sulit untuk meregangkan otot tubuh, dan memberikan tambahan beban pada tulang belakang dan sendi-sendi tubuh.

Hasil analisis usia responden menunjukkan persentase tertinggi responden yang mengalami nyeri punggung bawah adalah usia dewasa awal $(76,7 \%)$, yang lainnya adalah usia remaja akhir (10\%) dan dewasa tengah $(13,3 \%)$. Berdasarkan hasil observesi di lapangan, sebagian besar karyawan didominasi bagian marketing dengan usia pada rentang 19-30 tahun dan karyawan yang berusia di atas 30 tahun, seperti kepala bagian, operasional, driver, dan HRD (Human Resourch Development). Hal ini disebabkan karena marketing merupakan ujung tombak bagi suatu perusahaan, sehingga PT. Rifan Financindo sering melakukan recruitment bagi siswa SMA/SMK yang akan lulus, untuk ditempatkan di bagian marketing, oleh karena itu bagian marketing didominasi usia remaja hingga dewasa awal.

Hasil analisis di atas didukung dengan teori Singha (2014, dalam Maulana 2014, II 1-10) yang mengatakan bahwa sekarang nyeri punggung bawah tidak hanya menyerang usia tua saja, tetapi usia muda pun sekarang banyak yang mengalami nyeri punggung bawah, seperti pada kalangan mahasiswa dan pekerja kantoran. Nyeri punggung bawah pada usia muda disebabkan karena mereka kurang olahraga, aktivitas statis seperti terlalu banyak banyak duduk pada posisi yang sama dalam jangka waktu yang lama, misalnya belajar atau bekerja di balik meja. Bahkan duduk dengan posisi tubuh membungkuk saat membaca, menulis, berkerja di depan laptop, mengemudi kendaraan. Kondisi inilah yang menyebabkan terjadinya nyeri punggung bawah. Selain itu, orang muda di kota memiliki tingkat konsumsi makanan yang tinggi dan kurang olahraga, sehingga mengalami obesitas. Semakin meningkat berat badan seseorang maka, semakin sulit untuk meregangkan otot tubuh, dan memberikan tambahan beban pada tulang belakang dan sendi-sendi tubuh.

Teori lain mengatakan bahwa nyeri punggung bawah dapat dialami oleh siapa saja dan pada usia berapa saja. Namun, keluhan ini jarang dijumpai oleh seseorang yang berusia 0-10 tahun, hal ini berhubungan dengan faktor etiologik tertentu yang lebih sering dijumpai pada umur yang lebih tua. Nyeri punggung bawah biasanya dijumpai pada seseorang yang berumur dekade kedua dan insiden pada dekade kelima. Semakin bertambah usia terjadi perubahan degenerasi diskus intervertebra menjadi fibrokartilago yang padat dan tidak teratur, hal ini yang menjadi penyebab nyeri pungggung bawah. Nyeri tersebut biasanya terjadi pada lumbal keempat hingga sakrum pertama (Akbar, 2012, II 22; Lukman \& Nurna Ningsih, 2009, hlm.128).

Hasil analisis lama duduk responden menunjukkan sebagian besar duduk di kantor dalam waktu $>6$ jam per hari (60\%), dan yang lain duduk < 6 jam per hari (40\%). Berdasarkan hasil observasi peneliti di lapangan, kursi karyawan memiliki sandaran, tetapi sebagian besar karyawan duduk dengan posisi membungkuk dalam waktu yang lama, sehingga punggung tidak tertopang oleh sandaran kursi.

Hasil di atas didukung dengan teori yang mengatakan bahwa duduk dengan posisi statis dan postur tubuh yang salah dalam waktu lebih dari 2 jam per hari akan menyebabkan kekakuan otot punggung, 
peredaran darah pada punggung tidak lancar, dan meningkatkan tekanan dan beban pada diskus intervertebralis, ligamen dan bagian posterior dari tulang belakang, sehingga terjadi penimbunan asam laktat dan akhirnya menyebabkan nyeri punggung bawah (Akbar, 2012, II 24-26; International Labour Organitation, 2011, II 11; Ide, 2007, hlm.105-106).

Hasil analisis dari 30 responden menunjukkan sebagian besar masa kerja responden $\leq 5$ tahun $(93,3 \%)$. Berdasarkan hasil observasi di lapangan, diketahui bahwa responden paling banyak dialami oleh karyawan yang memiliki masa kerja $\leq 5$ tahun. Hal ini dikarenakan sebagian besar karyawan dengan masa kerja $\leq 5$ tahun belum pernah melakukan pekerjaan dalam posisi duduk dalam waktu yang relatif lama dan terus menerus dengan durasi 18 jam per hari bahkan terkadang ada waktu lembur 1-4 jam ditambah stressor dari lingkungan kerja.

Masa kerja menurut KBBI (Kamus Besar Bahasa Indonesia) (2016) adalah jangka waktu orang sudah berkerja (pada suatu kantor, badan, dan sebagainya). Masa kerja merupakan salah satu faktor yang risiko yang menyebabkan terjadinya nyeri punggung bawah. Hasil analisis ini didukung dengan penelitian Ayuningtyas (2012, hlm.4) yang menyatakan bahwa terdapat hubungan antara masa kerja dengan risiko terjadinya nyeri punggung bawah pada karyawan kantor PT. Krakatau Steel. Penelitian lain yang dilakukan oleh Rininingrum (2016, hlm.1) menyatakan bahwa terdapat pengaruh masa kerja terhadap keluhan low back pain. Masa kerja > 4 tahun memiliki risiko low back pain 11,711 kali lebih tinggi dibandingkan masa kerja $\leq 4$ tahun.

b. Gambaran Skala Nyeri Punggung Bawah Sebelum dan Sesudah Diberikan Sit Stretching pada Kelompok Intervensi

Berdasarkan hasil analisis menunjukkan bahwa skala nyeri punggung bawah pada kelompok intervensi sebelum diberikan sit stretching mayoritas pada skala nyeri 3 sebanyak 9 responden (40\%), dan yang lain pada skala 1, 4, dan 6. Skala nyeri punggung bawah sesudah diberikan sit stretching mayoritas pada skala nyeri 0 sebanyak 6 responden (40\%) dan yang lain pada skala nyeri 1, 2, dan 3. Pada data diatas mengambarkan bahwa terjadi penurunan skala nyeri punggung bawah dari skala nyeri 1-6 menjadi skala nyeri 0-3.

Hasil penelitian terkait yang dilakukan oleh Yulitania (2015, hlm.10) tentang "Perbedaan Pengaruh Peregangan dan William Flexion Exercise terhadap Nyeri Punggung Bawah Non Spesifik pada Pemetik Teh di Perkebunan Teh Jamus". Penelitian ini menyimpulkan bahwa terdapat perbedaan pengaruh antara latihan peregangan dan latihan William Flexione Exercise pada penurunan intensitas nyeri punggung bawah non spesifik pada pemetik teh di perkebunan teh Jumus pada tahun 2015.

Hasil analisis di atas diperkuat dengan teori Anderson (2008, hlm.14) yang mengatakan bahwa peregangan (stretching) merupakan latihan fisik yang berguna untuk mengurangi ketegangan otot, mempersiapkan tubuh sebelum beraktivitas, membuat tubuh menjadi rileks, memperluas rentang gerak, dan membantu mencegah terjadi cedera. Selain itu teori lain mengatakan bahwa latihan peregangan atau sit stretching yang dilakukan dengan benar dan rutin dapat meningkatkan fleksibilitas otot punggung, meningkatkan sirkulasi peredaran darah pada punggung, dan mampu mengurangi nyeri punggung bawah (Anderson, 2010, hlm.60, Lady, 2016, II 8; Marganti, 2016, II 1-6; Nainggolan, 2016, II 5).

c. Gambaran Skala Nyeri Punggung Bawah pada Kelompok Pembanding

Berdasarkan hasil analisis menunjukkan bahwa saat pre test mayoritas responden pada skala nyeri 3 sebanyak 5 responden $(33,3 \%)$ yang lainnya pada skala nyeri 1 , 
2, dan 5. Kemudian saat post test mayoritas responden tetap pada skala nyeri 3 sebanyak 5 responden $(33,3 \%)$, dan yang lain pada skala nyeri $0,1,2,5$, dan 7.

Penelitian terkait dilakukan oleh Okananto (2015, hlm.8-9) yang mengatakan bahwa hasil pre test menunjukkan sebagian besar pekerja mengalami keluhan nyeri pinggang dan nyeri punggung bawah pada tingkat keluhan rendah sebanyak 2 pekerja $(11,8 \%)$, tingkat keluhan sedang sebanyak 9 pekerja $(52,9 \%)$, tingkat keluhan tinggi sebanyak 6 pekerja $(35,3 \%)$ dan tidak ada responden yang mengalami keluhan pada tingkat sangat tinggi. Hasil post test menunjukkan tidak ada pekerja yang mengalami keluhan rendah dan sangat tinggi, sedangkan pada tingkat keluhan tinggi sebanyak 6 responden $(35,3 \%)$, dan banyak pekerja yang mengalami tingkat keluhan sedang, yaitu sebanyak 11 pekerja $(64,7 \%)$.

Pada saat penelitian pada kelompok pembanding tidak diberikan perlakuan berupa sit stretching hanya dilakukan pre test dan post test. Pre test pada kelompok pembanding dilakukan bersamaan dengan kelompok intervensi sebelum diberikan sit stretching pada hari pertama. Pada kelompok intervensi diberikan perlakuan sit stretching selama 5 hari. Hal ini dilakukan untuk membandingkan antara kelompok pembanding dengan kelompok intervensi apakah ada perbedaan yang signifikan atau tidak serta untuk mengetahui apakah dengan adanya pemberian sit stretching benar-benar berhasil. Berdasarkan hasil analisis pada kelompok intervensi dan kelompok pembanding dapat ditarik kesimpulan bahwa skala nyeri punggung bawah kelompok intervensi mengalami penurunan yang signifikan dibandingkan dengan kelompok pembanding.

\section{d. Analisis Bivariat}

Analisis bivariat menggunakan Mann Whitney karena data numerik (interval), tidak berdistribusi normal, dan pada dua kelompok tidak berpasangan. Hasil analisis menunjukkan bahwa mean rank kelompok intervensi terjadi penurunan dari 16,63 menjadi 10,33 sedangkan mean rank kelompok pembanding terjadi peningkatan dari 14,37 menjadi 20,67. Hal ini juga didukung dengan p-value skala nyeri punggung bawah saat post test diperoleh hasil 0,001 $(<0,05)$, yang menunjukkan bahwa terdapat perbedaan skala nyeri punggung bawah pada kelompok intervensi dengan kelompok pembanding. Peneliti menarik kesimpulan bahwa terdapat pengaruh sit stretching terhadap perubahan skala nyeri punggung bawah pada karyawan di PT Rifan Financindo Berjangka Cabang Semarang.

Perlakuan yang diberikan kepada kelompok intervensi berupa sit stretching mempunyai pengaruh terhadap perubahan skala nyeri punggung bawah. Hal ini dibuktikan dari hasil uji statistik menggunakan Mann Whitney diperoleh hasil p-value 0,001 dan terjadi penurunan mean rank skala nyeri punggung bawah pada kelompok intervensi dari 16,63 menjadi 10,33 . Penurunan skala nyeri punggung bawah disebabkan karena responden dilatih untuk melakukan gerakan-gerakan sit stretching dengan benar dan dilakukan secara rutin setiap hari selama 5 hari. Sedangkan, skala nyeri punggung bawah pada kelompok pembanding tidak terjadi perubahan yang signifikan, karena kelompok pembanding tidak tidak diberikan suatu perlakuan.

Hasil analisis di atas berkaitan dengan penelitian yang dilakukan oleh Nurdiati et al (2015, - 2) yang berjudul "Pengaruh Latihan Peregangan Terhadap Penurunan Intensitas Nyeri Pada Perawat yang Menderita Low Back Pain (LBP)". Hasil uji statistik menunjukkan $p$ value 0,000 $(\mathrm{p}<0,05)$ yang menunjukkan adanya pengaruh latihan peregangan terhadap penurunan intensitas nyeri pada perawat yang menderita low back pain.

Hasil penelitian lain yang dilakukan Okananto (2014, hlm.14) yang berjudul "Pengaruh Pemberian Peregangan (Stretching) terhadap Penurunan Keluhan Nyeri Pinggang dan Nyeri Punggung 
Bawah (Low Back Pain) pada Pekerja Bagian Menjahit CV. Vanilla Production Susukan Semarang". Kesimpulan penelitian Okananto yaitu ada pengaruh pemberian peregangan (stretching) pada pekerja menjahit terhadap keluhan nyeri pinggang dan nyeri punggung bawah pada kelompok perlakuan.

Hasil penelitian diatas diperkuat dengan penelitian yang dilakukan oleh Anggraeni (2015, hlm.3) yang berjudul "Manfaat Peregangan Otot terhadap Keluhan Nyeri Punggung Bawah pada Pekerja Bagian Knitting Gantung PT. Royal Korindah Purbalingga". Hasi uji statistik pada penelitian Anggraeni menunjukkan bahwa ada manfaat peregangan otot terhadap keluhan nyeri punggung bawah pada pekerja bagian knitting gantung PT. Royal Korindah Purbalingga.

Hasil penelitian dan jurnal-jurnal di atas juga didukung dengan teori yang mengatakan bahwa nyeri punggung bawah pada responden berhubungan erat dengan posisi tubuh ketika berkerja. Posisi tubuh responden ketika bekerja adalah duduk selama 1 hingga 8 jam bahkan lebih dalam sehari. Duduk yang terlalu lama akan membuat kekakuan otot abdomen dan punggung, peningkatan tekanan pada intervertebralis dan korpus vertebra, sehingga terjadi nyeri punggung bawah (International Labour Organitation, 2011, II 11; Tjokorda \& Maliawan, 2009, hlm. 55).

Teori Hawthorn \& Redmond (1998 dalam Kneale, 2011, hlm.163) mengatakan bahwa nyeri punggung bawah mengakibatkan kelemahan otot progresif, keletihan tubuh, hubungan personal dan sosial terganggu, dan penurunan produktivitas pekerja, sehingga menyebabkan kerugian ekonomi bagi perusahaan tersebut. Upaya untuk menurunkan nyeri punggung bawah dapat dilakukan beberapa terapi, salah satunya adalah sit stretching.
Sit stretching merupakan peregangan yang dilakukan dengan posisi duduk di kursi. Sit stretching adalah intervensi yang termasuk dalam pendekatan non farmakologi. Sit stretching yang dilakukan secara rutin akan bermanfaat untuk meregangkan otot punggung bawah yang mengalami kekakuan dan memperlancar peredaran darah yang akan meningkatkan sirkulasi oksigen dalam darah dan sel sehingga mengurangi timbunan asam laktat dalam otot punggung dan nyeri punggung bawah dapat berkurang. Karyawan yang duduk terlalu lama dalam posisi yang sama atau statis dianjurkan untuk melakukan peregangan ini supaya dapat menggerakkan otot-otot punggung bagian bawah dan memperlancar peredaran darah, sehingga dapat terhindar dari nyeri punggung bawah (Anderson, 2010, hlm. 37 \& 60; Lady, 2016, II 8; Marganti, 2016, I] 1-6; Nainggolan, 2016, II 5).

\section{SIMPULAN}

Berdasarkan hasil penelitian yang telah diuraikan dan dibahas, maka peneliti menarik kesimpulkan sebagai berikut :

1. Karakteristik responden yang berjumlah 30 responden, diketahui bahwa jenis kelamin laki-laki dan perempuan memliki persentase yang sama, yaitu $50 \%$. Usia responden yang mengalami nyeri punggung bawah didominasi usia dewasa awal (76,7\%) dibanding usia dewasa tengah $(13,3 \%)$ dan remaja akhir (10\%). Lama duduk responden di kantor sebagian besar duduk selama $>6$ jam per hari $(60 \%)$. Masa kerja responden sebagian besar $\leq 5$ tahun $(93,3 \%)$.

2. Skala nyeri punggung bawah pada kelompok intervensi setelah diberikan sit stretching sebagian besar terjadi penurunan skala nyeri punggung bawah, sedangkan skala nyeri punggung bawah kelompok kontrol sebagian besar tidak terjadi perubahan skala nyeri punggung bawah, tetapi terdapat 1 responden terjadi penurunan serta terdapat 4 responden peningkatan skala nyeri punggung bawah.

3. Berdasarkan uji statistik menggunakan Mann Whitney diperoleh p-value 0,001, sehingga dapat disimpulkan bahwa terdapat 
pengaruh sit stretching terhadap perubahan skala nyeri punggung bawah pada karyawan PT. Rifan Financindo Berjangka Cabang Semarang.

\section{SARAN}

1. Bagi Tempat Penelitian

Karyawan diharapkan dapat melakukan sit stretching atau peregangan lainnya di selasela pekerjaan, saat istirahat, dan setelah bekerja dengan tujuan untuk menjaga sirkulasi peredaran darah tetap lancar ke seluruh anggota tubuh. Sikap kerja dianjurkan tidak dalam keadaan statis, seperti duduk dengan membungkuk dalam waktu yang lama yang dapat mengakibatkan kekakuan otot dan nyeri punggung bawah. Selain itu, PT Rifan Financindo diharapkan dapat membuat program untuk diadakan senam atau olahraga secara rutin, misalnya satu minggu sekali untuk menjaga kebugaran tubuh karyawannya.
2. Bagi Institusi Pendidikan

Penelitian ini diharapkan dapat menjadi sumbangan ilmiah bagi perkembangan ilmu keperawatan komunitas. Peneliti menyarankan perawat dan institusi pendidikan tidak hanya meninjau kesehatan yang berada di lingkungan rumah sakit saja tetapi memperhatikan kesehatan di tempat kerja (kantor dan industri) sebagai langkah promotif dan preventif terhadap suatu penyakit.

3. Bagi Peneliti Selanjutnya

Penelitian ini diharapkan dapat menjadi informasi tambahan bagi peneliti selanjutnya mengenai manfaat sit stretching terhadap perubahan skala nyeri punggung bawah. Bagi Peneliti selanjutnya perlu melakukan penelitian lebih lanjut tentang nyeri punggung bawah dengan mengembangkan variabel-variabel lain yang dapat menurunkan nyeri punggung bawah serta mengontrol faktorfaktor yang mempengaruhi nyeri punggung bawah seperti faktor budaya, psikososial, dan spiritual.

(NPB) pada karyawan PT. Krakatau Steel di Cilegon Banten. http://eprint.ums.ac.id/21930/19/Naskah _publikasi_santie.pdf. diakses tanggal 13 Mei 2017.

International Labour Organitation (ILO).

(2011). Musculoskeletal system-Low back

region.http://www.iloencyclopaedia.org/ part-i-47946/musculoskeletal-system

/17-6-musculoskeletal-system/low-

back-region. diakses tanggal 16

Desember 2016.

KBBI (Kamus Besar Bahasa Indonesia). (2016). Masa kerja. http://kbbi.web.id/masa. diakses tanggal 16 Mei 2017.

antara masa kerja dengan risiko terjadinya nyeri punggung bawah 
Lady, Queen. (2016). Sepuluh manfaat reguler peregangan untuk rugi berat dan kesehatan.

http://queenladdy.com/id/pages/474876. dikases tanggal 17 Maret 2017.

Lukman, Nurna Ningsih. (2009). Asuhan keperawatan pada klien dengan gangguan sistem muskuloskeletal. Jakarta : Medika Salemba.

Maulana, Yati. (2014). Sembilan penyebab sakit punggung mulai menyerang anak muda.

https://indonesiana.tempo.co/read/8231/ 2014/01/27/yatimaulana/9-penyebabsakit-punggung-mulai-menyerang-anakmuda. diakses tanggal 20 Mei 2017.

Nainggolan, Sri Yanti. (2016). Manfaat peregangan bagi tubuh.

http://m.metrotv-

news.com/rona/kesehatan/2NPoa79k-

manfaat-peregangan-bagi-tubuh. diakses tanggal 17 Maret 2017.

Nurdiati, Wiwit, Gamya T. U., Sri U. (2015). Pengaruh latihan peregangan terhadap penurunan intensitas nyeri pada perawat yang menderita low back pain $(L B P) \quad$ Vol. $2 . \quad$ No. 1. http://jom.unri.ac.id/index.php/

JOMPSIK/ article/view/8340/. diakses tanggal 21 Juni 2016.

Okanato, Adi. (2014). Pengaruh pemberian peregangan (stretching) terhadap penurunan keluhan nyeri pinggang dan nyeri punggung bawah (low back pain) pada pekerja bagian menjahit $C V$. Vanilla Production Susukan Semarang. http://eprints.ums.ac.id/32682/22/NASK AH\%20PUBLIKASI.pdf. diakses tanggal 22 Mei 2017.

Tjokorda Mahadewa G.B., Sri Maliawan.

(2009). Diagnosis dan tatlaksana.

Kegawata daruratan tulang belakang.

Jakarta : FKU Universitas Indonesia.

diakses tanggal 27 Januari 2017.
Warapsari, Dyah Lathu, Zaenal Sugiyanto, dan

Eko Hartini. (2014). Hubungan posisi

kerja dan waktu kerja terhadap nyeri

pinggang bawah (low back pain) pada

pekerja pengolahan bandeng presto

Kelurahan Bandengan Kecamatan

Kendal.http://eprint.dinus.ac.id/7933/

diakses tanggal 17 Desember 2016.

World Health Organization (WHO). (2014). WHO | Regional estimates for 2000 2011[Online]. Available at: http://www.who.int/healthinfo/

global burden disease /estimates regional/en/ index1.html/. diakses tanggal 17 April 2016.

Wulandari, Reisma. (2013). Perbedaan tingkat nyeri punggung bawah pada pekerja pembuatan teralis sebelum dan sesudah pemberian edukasi peregangan di Kecamatan CilacapTengah Kabupaten Cilacap vol 2, no.l. download.portalgaruda.org/article.php?a rticle $=73973 \& v a l=4700 / . \quad$ diakses tanggal 17 April 2016.

Yulitania, Desi Dyah. (2015). Perbedaan pengaruh peregangan dan william flexion exercise terhadap nyeri punggung bawah non spesifik pada pemetik teh di perkebunan teh jamus. http://eprints.ums.ac.id/39199/HALAM AN\%20 DEPAN.pdf. diakses tanggal 16 April 2016. 